\title{
ROLE OF ESCHERICHIA COLI $\beta$-KETOACYL-ACP SYNTHASE I IN UNSATURATED FATTY ACID SYNTHESIS
}

\author{
by
}

\author{
MADS SIGGAARD-ANDERSEN
}

\author{
Department of Physiology, Carlsberg Laboratory \\ Gamle Carlsberg Vej 10, DK-2500 Copenhagen Valby \\ and \\ Institute of Genetics, University of Copenhagen \\ Øster Farimagsgade 2A, DK-1353 Copenhagen K
}

Keywords: Cerulenin, $f a b B, f a b F$, $\beta$-ketoacyl-ACP synthase II, fatty acid synthetase

\begin{abstract}
Two activities were found in E. coli extracts which could complement unsaturated fatty acid synthesis of a cerulenin treated $\mathrm{E}$. coli fatty acid synthetase. One of these is $\beta$-ketoacyl-ACP synthase $\mathrm{I}$, but it is not known whether the other activity represents the previously characterized $\beta$-ketoacyl-ACP synthase II. A mutant strain exhibiting a temperature sensitive unsaturated fatty acid synthetic activity apparently lacked an active $\beta$-ketoacyl-ACP
\end{abstract} synthase I.

\section{INTRODUCTION}

Phospholipids of E. coli are almost exclusively esters of the saturated palmitic acid and the unsaturated palmitoleic and $c i s$-vaccenic acids (21). A common intermediate in the pathways leading to these fatty acid products is $(R)$-3-hydroxydecanoyl-ACP, which is dehydrated to either $(E)$-2-decenoyl-ACP or $(Z)$-3-decenoyl$\mathrm{ACP}(27)$, marking the start of the saturated and unsaturated pathways. The condensation reactions after this division are carried out by $\beta$-ketoacyl-ACPsynthase I and II, the products of the $f a b B$ and $f a b F$ genes, respectively $(5,7)$. $\beta$-ketoacyl-ACP synthase I is necessary for a reaction early in the unsaturated pathway $(5,25)$, while only $\beta$-ketoacyl-ACP synthase II can catalyze the last reaction of this pathway, namely the elongation of palmitoyl-ACP to $c i s$-vaccenoylACP (8). Both are believed to carry out all condensation reactions of the saturated pathway, since neither $f a b B(3)$ nor $f a b F(9)$ mutants show a requirement for saturated fatty acids.

The ratio of saturated to unsaturated fatty acids in phospholipids of $E$. coli varies with growth temperature (15) and is, at least in part, controlled at the level of enzyme activities of the fatty acid synthetase (2). This regulation has been attributed to a temperature dependency of $\beta$-ketoacyl-ACP synthase II in the last elongation reaction of the unsaturated pathway (8), but

Abbreviations: $\mathrm{ACP}=$ acyl carrier protein; EDTA = ethylene diamino tetraacetic acid; $\mathrm{TLC}=$ thin layer chromatography. 
regulation at other points has also been suggested $(19,20,28)$.

In this paper cerulenin, an antibiotic isolated from Cephalosporium caerulens (16), is used to inhibit unsaturated fatty acid synthesis of E. coli (1). Wild type E. coli was found to have two activities which could reconstitute unsaturated fatty acid synthesis in such a preparation. One of these activities is $\beta$-ketoacyl-ACP synthase I. This activity was apparently missing in a mutant strain which exhibits a temperature dependent requirement for unsaturated fatty acids.

\section{MATERIALS AND METHODS}

\subsection{Strains, media and crude protein} preparation

As source of protein which was considered wild type with respect to fatty acid synthetase, the E. coli strain LE392 (18) was used. The other E. coli strains studied were the conditional unsaturated fatty acid auxotrophic DM86 $\left[L E 392, s t r^{R}, f a b B^{t s}\right](17)$, and a derivative of DM86 termed DM86 pfabB 1 harboring a plasmid carrying the E. coli strain B fabB gene (12).

The media for strains LE392 and DM86 was LB (14), while that for strain DM86 pfabB1 was LB containing $50 \mathrm{mg} \cdot \mathrm{l}^{-1}$ of ampicillin. Cells were grown at $37^{\circ} \mathrm{C}$ until the end of the exponential growth phase, when they were harvested by a low speed centrifugation. After being washed once in a buffer of $20 \mathrm{mmol} \cdot 1^{-1}$ Tris- $\mathrm{HCl}$ at $\mathrm{pH} 8.0,1 \mathrm{mmol} \cdot 1^{-1}$ EDTA, $10 \mathrm{mmol} \cdot 1^{-1}$ 2-mercaptoethanol and $100 \mathrm{mmol} \cdot 1^{-1} \mathrm{NaCl}$, they were resuspended in a minimum volume of the same buffer and run twice through a French pressure cell at $150 \mathrm{MPa}$. The crude extract of soluble proteins was recovered by a $90 \mathrm{~min}$ centrifugation at $135,000 \cdot g$ followed by a filtration of the supernatant $(220 \mathrm{~nm}$ filter, Millex GV, Millipore).

\subsection{Separation and detection of $\left[{ }^{3} \mathrm{H}\right]$-cerulenin labelled proteins}

$\left[{ }^{3} \mathrm{H}\right]$-cerulenin in acetone, prepared by ${ }^{3} \mathrm{H}$ exchange in ${ }^{3} \mathrm{H}_{2} \mathrm{O}$, was provided by Amersham tritium labelling service and used without purification, although it contained several labelled compounds which were separable by TLC. 230 pmol of $\left[{ }^{3} \mathrm{H}\right]$-cerulenin $\left(57 \mathrm{TBq} \cdot \mathrm{mol}^{-1}\right)$ was transferred to a test tube, and the acetone evaporated under a stream of $\mathrm{N}_{2} .100 \mu \mathrm{l}$ of crude protein extract, at $10-30 \mathrm{~g} \cdot 1^{-1}$, was then added. After $30 \mathrm{~min}$ at $25^{\circ} \mathrm{C}$ the sample was desalted into $20 \mathrm{mmol} \cdot \mathrm{I}^{-1}$ Tris- $\mathrm{HCl}$ at $\mathrm{pH} 8.0$, on a $100 \times 10 \mathrm{~mm}$ column of Sephadex G-25 SF (Pharmacia). The desalted sample was anion exchanged in the same buffer on a $50 \times 5 \mathrm{~mm}$ column of Mono-Q (Pharmacia), in a $55 \mathrm{ml}$ gradient of $\mathrm{NaCl}$ from 0 to $1 \mathrm{~mol} \cdot \mathrm{l}^{-1}$ at 1.5 $\mathrm{ml} \cdot \mathrm{min}^{-1}$. Radioactivity was monitored by continuous flow liquid scintillation counting using an LB 505 instrument (Berthold).

\subsection{Protein fractionation}

Crude protein extract (100-300 mg of protein) was dialyzed against a buffer containing 20 $\mathrm{mmol} \cdot \mathrm{l}^{-1}$ Tris- $\mathrm{HCl}$ at $\mathrm{pH} 8.0$ and $10 \mathrm{mmol} \cdot \mathrm{l}^{-1}$ 2 -mercaptoethanol. The dialyzed sample was anion exchanged in the same buffer on a $100 \times 10$ $\mathrm{mm}$ column of Mono-Q, using a gradient of $\mathrm{NaCl}$ from 0 to $1 \mathrm{~mol} \cdot{ }^{-1}$ in 11 at $4 \mathrm{ml} \cdot \mathrm{min}^{-1}$. Fractions of 5-10 $\mathrm{ml}$ were collected.

\subsection{Enzyme assays}

In vitro fatty acid synthetase assays contained $1 \mathrm{mmol} \cdot 1^{-1} \mathrm{NADPH}, 1 \mathrm{mmol} \cdot \mathrm{l}^{-1} \mathrm{NADH}, 2$ $\mathrm{mmol} \cdot 1^{-1}$ dithiotreitol and $10 \mu \mathrm{mol} \cdot 1^{-1}$ acetylCoA (all from Sigma), a total of $60 \mu \mathrm{mol} \cdot \mathrm{I}^{-1}$ malonyl-CoA (Sigma), including $33 \mathrm{kBq}$ [2${ }^{14} \mathrm{C}$ ]-malonyl-CoA (New England Nuclear, 1.58 $\left.\mathrm{TBq} \cdot \mathrm{mol}^{-1}\right), 20 \mathrm{mg} \cdot \mathrm{I}^{-1}$ of E. coli ACP purified by published procedures (24), $2 \mathrm{~g} \cdot \mathrm{I}^{-1}$ of $\mathrm{E}$. coli crude protein extract, and $100 \mathrm{mmol} \cdot \mathrm{l}^{-1}$ of $\mathrm{K}-\mathrm{PO}_{4}$ at $\mathrm{pH} 6.8$ in a total volume of $500 \mu \mathrm{l}$. For inhibition experiments the crude protein extract was incubated with cerulenin (Sigma) for 30 minutes at $37^{\circ} \mathrm{C}$ before being used in the assays. Cerulenin concentrations are as given in section 3 . In complementation experiments the crude protein extract was likewise treated with 20 $\mu \mathrm{mol} \cdot \mathrm{l}^{-1}$ cerulenin, but the assay mix differed in also containing $100 \mu \mathrm{l}$ of the fraction to be tested. Assays were carried out at $37{ }^{\circ} \mathrm{C}$ and stopped after $150 \mathrm{~min}$ by adding $\mathrm{NaOH}$ to a final concentration of $2 \mathrm{~mol} \cdot \mathrm{I}^{-1}$. 


\subsection{Identification and quantification of fatty acids}

Free fatty acids were prepared by saponification in $2 \mathrm{~mol} \cdot \mathrm{l}^{-1} \mathrm{NaOH}$ at $80^{\circ} \mathrm{C}$ for $30 \mathrm{~min}$. After acidification with $\mathrm{H}_{2} \mathrm{SO}_{4}$, the fatty acids were extracted with n-hexane, and dried under $\mathrm{N}_{2}$. Conversion to the corresponding methyl esters was then performed by adding $2.5 \mathrm{ml} 12 \%$ $\mathrm{BF}_{3}-\mathrm{CH}_{3} \mathrm{OH}$ complex, and letting the reaction proceed for 30 minutes at $80^{\circ} \mathrm{C}$. Two ml of $\mathrm{H}_{2} \mathrm{O}$ was added and the methyl esters extracted into n-hexane. Separation of the methyl esters was performed on a Packard model 437 gas chromatograph. The column used was a $10 \mathrm{~m} \mathrm{CP}$-Sil $5 \mathrm{CB}$ of $530 \mu \mathrm{m}$ inner diameter and $5 \mu \mathrm{m}$ wall coating (Chrompac) operated with helium as carrier gas at a flow-rate of $15 \mathrm{~cm} \cdot \mathrm{s}^{-1}$. The temperature program was $5 \mathrm{~min}$ at $100^{\circ} \mathrm{C}$ and then a temperature gradient from 100 to $310^{\circ} \mathrm{C}$ at $2{ }^{\circ} \mathrm{C} \cdot \mathrm{min}^{-1}$. A Packard model 894 gas proportional counter operated with helium as carrier gas at a flow rate of $55 \mathrm{ml} \cdot \mathrm{min}^{-1}$ and propane as quench gas at $5 \mathrm{ml} \cdot \mathrm{min}^{-1}$ was used to quantify the ${ }^{14} \mathrm{C}$ labelled compounds. Identification was by comparison with appropriate standards.

\section{RESULTS}

\subsection{Cerulenin binding proteins}

Cerulenin is known to specifically inhibit a number of $\beta$-ketoacyl-thioester synthases $(4,29)$ by an irreversible mechanism (4). Low concentrations of cerulenin inhibit the growth of E. coli by selectively blocking unsaturated fatty acid synthesis (1). This effect is thought to be caused by inhibition of $\beta$-ketoacyl-ACP synthase I (1), a key enzyme in unsaturated fatty acid synthesis (25). Therefore, low concentrations of $\left[{ }^{3} \mathrm{H}\right]$ cerulenin were used to tag the cerulenin binding proteins of crude protein extracts as part of a purification procedure for $\beta$-ketoacyl-ACP synthase I (12). This approach for studying cerulenin sensitive activities has previously been applied to the erythronolide synthase of Streptomyces erythreus (23) using the less specific $\left[{ }^{3} \mathrm{H}\right]$-tetrahydrocerulenin $(4,22)$.

In the present experiments crude protein extracts from the wild type E. coli strain LE392, the temperature sensitive DM86 and the plasmid bearing DM86 pfabB1 were incubated with

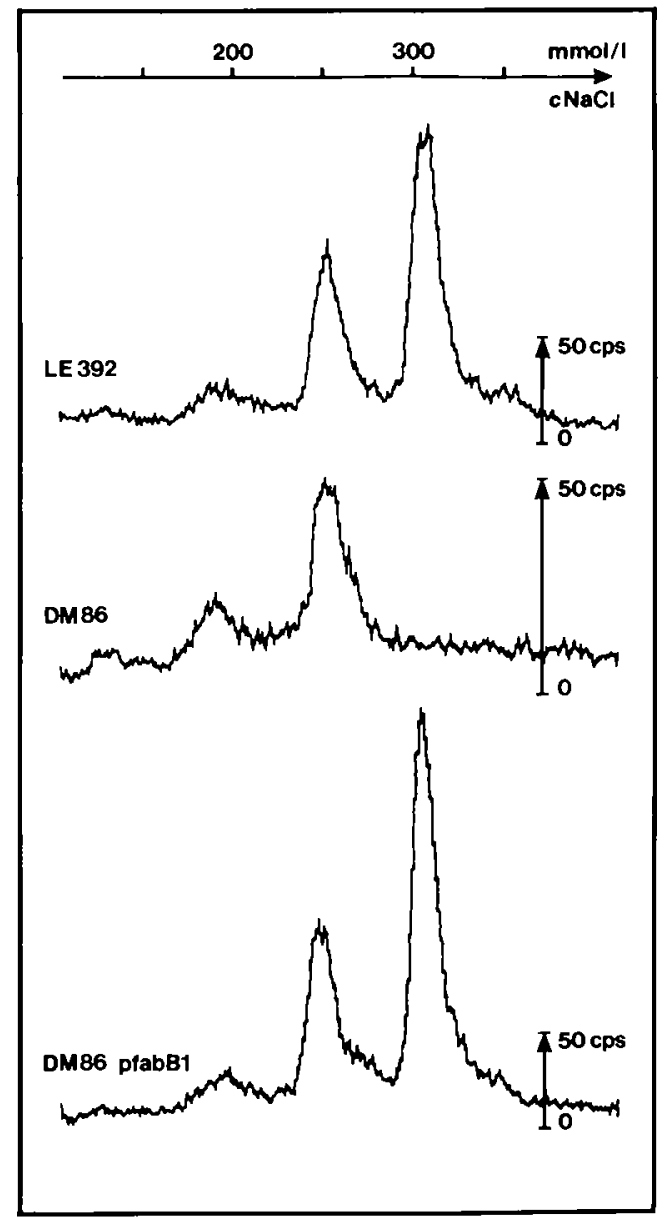

Figure 1. Cerulenin binding proteins of E. coli strains LE392, DM86 and DM86 pfabB1. [ $\left.{ }^{3} \mathrm{H}\right]-$ cerulenin labelled proteins were separated and detected as described in section 2.2. The top scale gives the salt concentration of the eluent.

$2.3 \mu \mathrm{mol} \cdot \mathrm{I}^{-1}\left[{ }^{3} \mathrm{H}\right]$-cerulenin. Subsequently, the proteins were fractionated by anion exchange chromatography and ${ }^{3} \mathrm{H}$ labelled proteins detected by continuous flow scintillation counting. As shown in Figure 1 two prominent peaks are seen in the crude protein extracts from strains LE392 and DM86 pfabB1, while extracts of strain DM86 apparently possessed only one of them. The later eluting peak corresponds to $\left[{ }^{3} \mathrm{H}\right]$-cerulenin labelled $\beta$-ketoacyl-ACP synthase I which has been purified and partially sequenced (12), and thereby shown to be the 


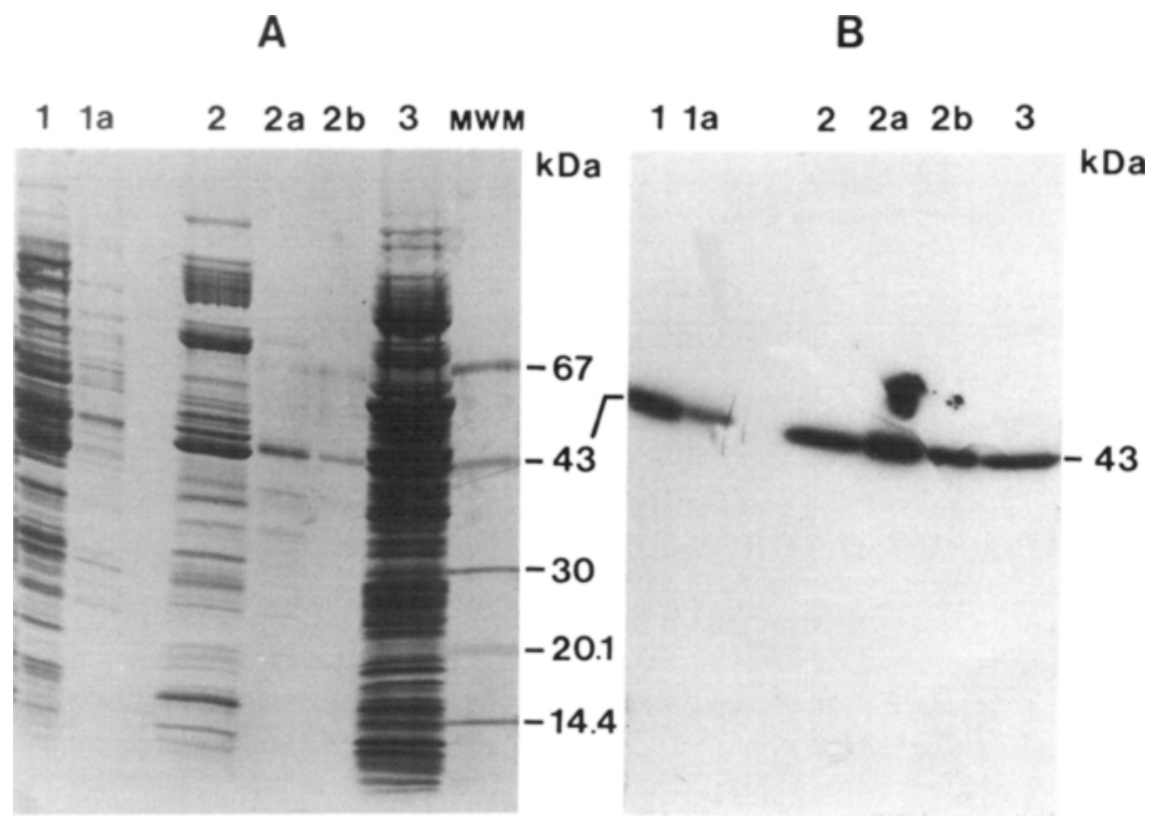

Figure 2. $\left[{ }^{3} \mathrm{H}\right]$-cerulenin labelled proteins were fractionated as described in section 2.3 , and samples analyzed by SDS-PAGE on a $7.5-15 \%$ gel essentially according to LAEMMLI (13). A: Coomassie brilliant blue stain. B: Fluorography using sodium-salicylate. Lane 1 : Ion exchange fraction that contained only the first eluting prominent radioactive peak (Fig. 1). 2: Ion exchange fraction that included only the second eluting prominent radioactive peak (Fig. 1), which contains [ $\left.{ }^{3} \mathrm{H}\right]$-cerulenin labelled $\beta$-ketoacyl-ACP synthase I. 3: Crude protein extract of E. coli LE392. MWM: molecular weight markers (Pharmacia).

The remaining lanes illustrate various additional purification steps of the two cerulenin binding proteins. Lane 1a: Fraction from ion exchange at pH 6.0 of the protein shown in lane 1. 2a: Fraction from ion exchange at pH 6.0 of the protein shown in lane 2. $2 b$ : Fraction from gel filtration of the protein shown in lane $2 a$.

product of the $f a b B$ gene. Strain LE392 carries a wild type $f a b B$ allele, while strain DM86 pfabB 1 harbors a wild type $f a b B$ allele on a plasmid. The phenotype of the mutant strain DM86 has been attributed to a temperature sensitive $\beta$-ketoacyl-ACP synthase I activity. The inability to detect a cerulenin binding protein corresponding to this enzyme may be caused by the mutation rendering the enzyme unstable to the experimental conditions or unable to bind cerulenin.

To determine the molecular masses of the two cerulenin binding proteins, samples were analyzed by SDS-PAGE and the labelled proteins identified by fluorography as shown in Figure 2 . Both proteins had an apparent molecular mass of $43 \mathrm{kDa}$, and therefore appear as a single labelled band in the wild type LE392 crude protein extract. The figure also demonstrates the specific $\left[{ }^{3} \mathrm{H}\right]$-cerulenin labelling of the crude LE392 extract (Fig. 2, lane 3).

The relative amount of label eluting with each of the two prominent peaks differed from one enzyme preparation to the next. Separate labellings of the same preparation, however, always gave the same result. It is not known whether this variation is introduced in the extraction procedure or reflects different relative amounts of the proteins in the cells used as starting material. The differences in absolute labelling of protein from each of the three strains (Fig. 1) was caused by disparate protein concentrations. Interestingly, in some experiments a third radioactive peak was observed 


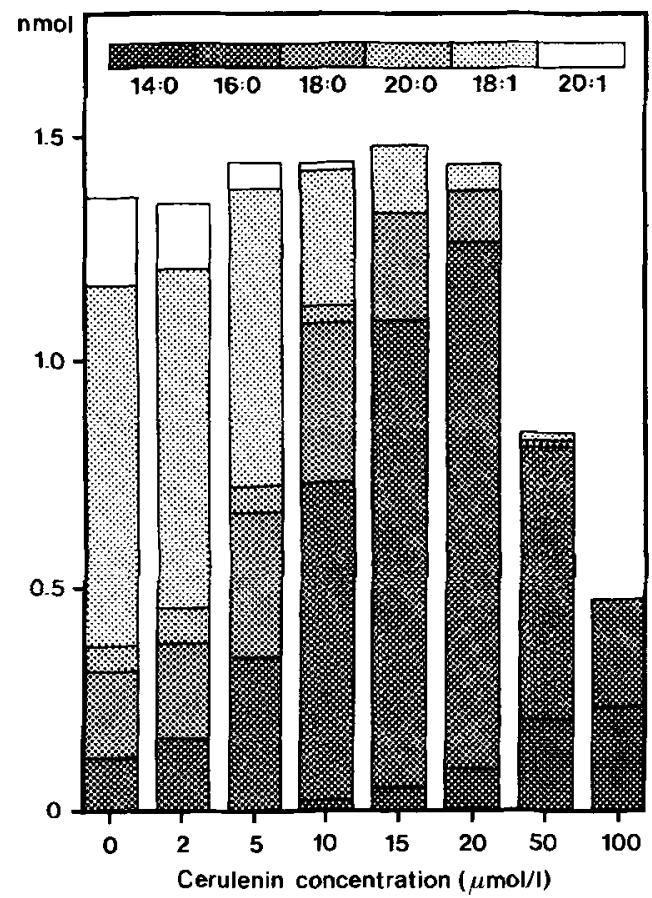

Figure 3. Cerulenin inhibition of fatty acid synthetase. Crude protein extracts of E. coli strain LE392 were incubated with the indicated concentrations of cerulenin before assaying for fatty acid synthetase activity as described in section 2.4 . The fatty acids found in amounts greater than $25 \mathrm{pmol}$ were 14:0 = tetradecanoic acid (myristic acid), 16:0 = hexadecanoic acid (palmitic acid), 18:0 = octadecanoic acid (stearic acid), 20:0 = eicosanoic acid (arachidic acid), 18:1 = (Z)-11octadecenoic acid (cis-vaccenic acid), 20:1 = (Z)-13eicosenoic acid.

eluting at $270 \mathrm{mmol} \cdot 1^{-1} \mathrm{NaCl}$. By SDS-PAGE this labellę protein was judged to have a molecular mass of $50 \mathrm{kDa}$ (results not shown).

\subsection{Inhibition of fatty acid synthetase}

To determine if one of the cerulenin binding proteins (Fig. 1) was $\beta$-ketoacyl-ACP synthase I, a complementation assay was set up for its activity in unsaturated fatty acid synthesis. This required establishing the conditions for specifically inhibiting unsaturated fatty acid synthesis of an E. coli extract. Crude protein extracts from strain LE392 were therefore treated with various

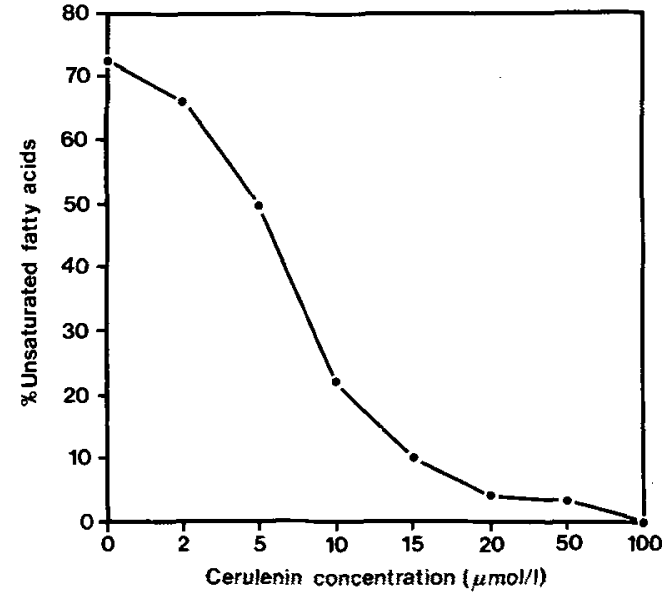

Figure 4. Percent unsaturated $\mathrm{C}_{12}-\mathrm{C}_{20}$ fatty acids as calculated from the results presented in Figure 3.

concentrations of cerulenin before assaying the fatty acid synthetase activity. The amount of each $\mathrm{C}_{12}-\mathrm{C}_{20}$ fatty acid produced in these assays is illustrated in Figure 3. When the cerulenin concentration was brought from 0 to $20 \mu \mathrm{mol} \cdot \mathrm{l}^{-1}$, the total fatty acid synthesis remained constant (Fig. 3) while the proportion of unsaturated fatty acids decreased from $72 \%$ to $5 \%$ (Fig. 4). At

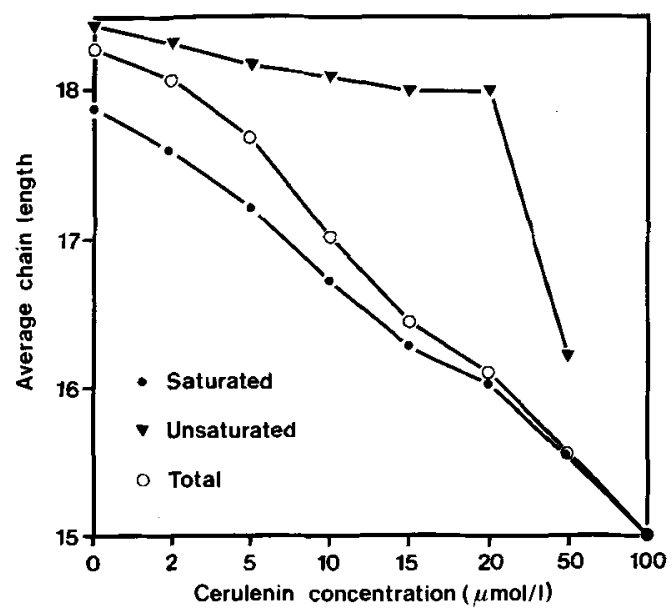

Figure 5. Average chain length of $\mathrm{C}_{12}-\mathrm{C}_{20}$ saturated, unsaturated and total fatty acids as calculated from the results presented in Figure 3. 
higher concentrations of cerulenin the total synthetic activity was also impaired (Fig. 3). Therefore, cerulenin at $20 \mu \mathrm{mol} \cdot \mathrm{l}^{-1}$ was used for the complementation assays presented in section 3.3.

To further study the effect of cerulenin in these assays, the chain lengths of the recovered $\mathrm{C}_{12}-\mathrm{C}_{20}$ fatty acids were analyzed. The average chain length of the unsaturated fatty acid products remains relatively constant at least up to 20 $\mu \mathrm{mol} \cdot \mathrm{l}^{-1}$ cerulenin (Fig. 5) while their relative contribution to total fatty acids decreases from $72 \%$ to $5 \%$ (Fig. 4). This indicates that once the double bond has been introduced other enzymes than the one being inhibited by cerulenin can carry out further elongation of unsaturated fatty acids. With increasing cerulenin concentrations a shortening of the saturated fatty acids is observed (Fig. 5). This decrease in average chain length, however, is paralleled by an increase in total synthesis of saturated fatty acids (Fig. 3). It can therefore not be concluded that the reduction in chain length is caused by inhibition of an enzyme in the pathway leading to saturated fatty acids.

\subsection{Complementation of fatty acid synthesis}

Crude protein extracts from the three strains studied were fractionated by anion exchange, and the fractions tested for their ability to complement a wild type fatty acid synthetase which had been treated with $20 \mu \mathrm{mol} \cdot \mathrm{l}^{-1} \mathrm{ceru}$ lenin. The total amount of fatty acid synthesized $(1.4-1.5 \mathrm{nmol})$ was not affected by these additions. This is in accordance with the observation that $20 \mu \mathrm{mol} \cdot 1^{-1}$ cerulenin does not reduce total fatty acid synthesis (Fig. 3). Complementation of unsaturated fatty acid synthesis was afforded by a number of fractions as illustrated in Figure 6 . These same fractions increased the length of saturated fatty acids as shown in Figure 7, while none of them had an observable effect on the average chain length of unsaturated fatty acids. This result was expected, since treatment of the crude extract with cerulenin had a profound effect on the amount of unsaturated fatty acids (Fig. 4) and on chain length of the saturated fatty acids (Fig. 5), while the influence on unsaturated fatty acid chain length was much smaller (Fig.

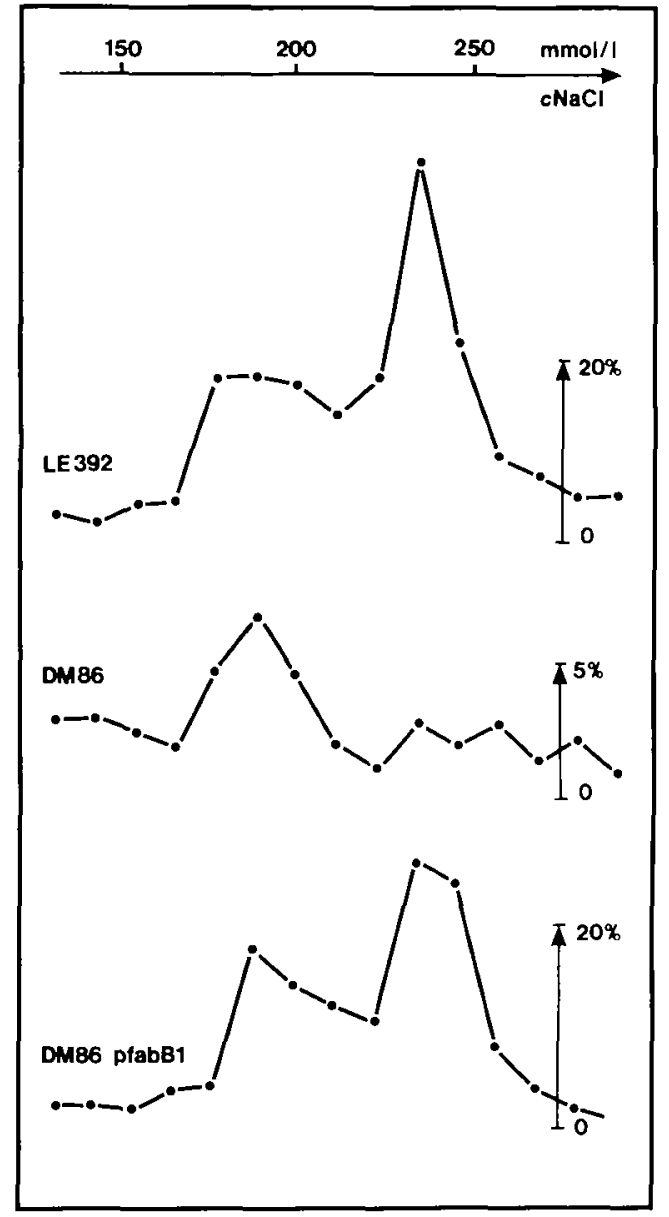

Figure 6. Complementation of unsaturated fatty acid synthesis. Ion exchange fractions of protein from strains LE392, DM86 and DM86 pfabB1 were tested for their ability to restore unsaturated fatty acid synthesis in a crude protein extract of strain LE392 which had been treated with $20 \mu \mathrm{mol} \cdot \mathrm{H}^{-1}$ cerulenin (sections 2.3 and 2.4). The amount of unsaturated fatty acids recovered is expressed as percent of total $\mathrm{C}_{12}-\mathrm{C}_{20}$ fatty acids. The top scale gives the salt concentration of the eluent. As a result of different chromatographic conditions (sections 2.2 and 2.3) the elution positions are not directly comparable to those presented in Figure 1.

5). Two activities were observed when fractions from LE392 and DM86 pfabB1 were assayed, while extracts of DM86 only possessed the first eluting of these activities. If the same chromatographic conditions were used as those in the experiment presented in Figure 1, the two activ- 


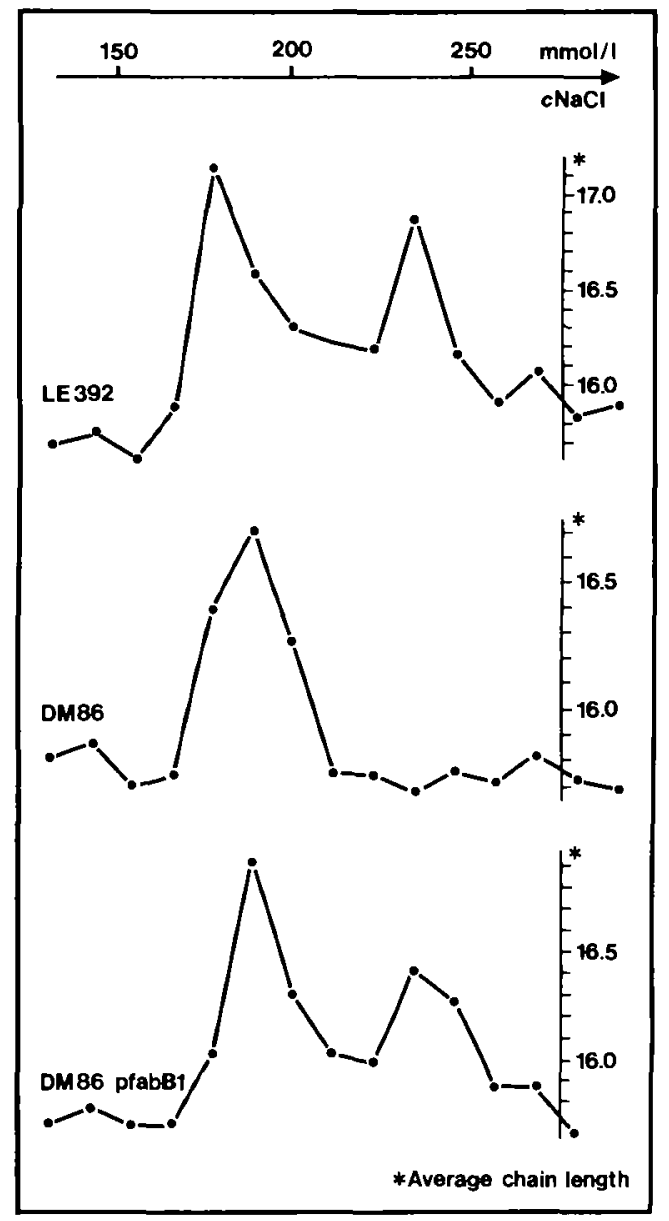

Figure 7. Average chain length of $\mathrm{C}_{12}-\mathrm{C}_{20}$ saturated fatty acids resulting from the complementation experiments presented in Figure 6.

ities elute in the same fractions as the cerulenin binding proteins (section 3.1). That is, fractions containing cerulenin binding proteins also contain activities that will complement cerulenin treated fatty acid synthetase. This infers that both the cerulenin binding proteins are involved in fatty acid synthesis. As both activities independently bypass the block which was introduced by cerulenin, they presumably catalyze the same type of reaction, which implies that the first eluting activity is also a $\beta$-ketoacyl synthase.

Comparison of the results presented in Figures 6 and 7 suggests that the first eluting activity may be relatively more efficient in elongating saturated fatty acids than the second activity. Conclusions with respect to the specificities of the complementing activities can, however, not be drawn on the basis of these results since the fractions tested may also contain other enzymes involved in fatty acid synthesis. As was the case with $\left[{ }^{3} \mathrm{H}\right]$-cerulenin labelling (section 3.1 ), the differences in absolute activities observed with each of the three strains are attributed to differences in protein concentrations.

Preliminary studies of the two activities from strain LE392 indicate that the $\beta$-ketoacyl-ACP synthase I activity is irreversibly lost at $43^{\circ} \mathrm{C}$ with a half life of $5 \mathrm{~min}$, while the first eluting activity appeared to be stable at this temperature. Half lives of $14 \mathrm{~min}(25)$ and $18 \mathrm{~min}(5)$ have previously been reported for $\beta$-ketoacylACP synthase $I$ at $43^{\circ} \mathrm{C}$, although other workers found the enzyme to be relatively stable with a half life of $80 \mathrm{~min}$ at $42{ }^{\circ} \mathrm{C} \mathrm{(7).} \mathrm{In} \mathrm{this} \mathrm{latter}$ work, a $f a b B^{i s}$ mutant was found to have a $\beta$-ketoacyl-ACP synthase I which lost $50 \%$ of its activity in $9 \mathrm{~min}$ at $42{ }^{\circ} \mathrm{C}$. The reason for this discrepancy remains unknown.

\section{DISCUSSION}

By ion exchange chromatography two cerulenin binding proteins were separable in wild type E. coli extracts (Fig. 1). The fractions containing these proteins also contain enzyme activities which will reconstitute unsaturated fatty acid synthesis of extracts where the latter has been inhibited by cerulenin (Fig. 6).

The identification of the second eluting activity as $\beta$-ketoacyl-ACP synthase I was ascertained by comparison of its properties with published data. As previously found, the enzyme is involved in unsaturated fatty acid synthesis (5), is sensitive to cerulenin (1) and has a subunit molecular mass of $43 \mathrm{kDa}(8)$. In an accompanying paper (12) also the amino acid composition $(8)$ and map position of its gene $(6,26)$ were found to match those of $\beta$-ketoacyl-ACP synthase I.

Assignment of the first eluting activity to a characterized enzyme has not been possible on the basis of the present results. The only known candidates are the acetoacetyl synthase (11) and the $\beta$-ketoacyl-ACP synthase II. The former is 
ruled out by its insensitivity to cerulenin and by only being able to elongate very short chain substrates (11). $\beta$-ketoacyl-ACP synthase II has been reported to have a molecular mass slightly, albeit significantly, higher than that of $\beta$-ketoacyl-ACP synthase I $(5,8)$. No difference was detected in the molecular masses of the two cerulenin binding proteins studied herein. However, the bound cerulenin could alter the SDS binding properties of the proteins, and thereby their apparent molecular masses in SDS-PAGE. Complementation of unsaturated fatty acid synthesis by $\beta$-ketoacyl-ACP synthase II has previously been reported (5), although the observed activity was much lower than that seen for the first eluting activity in these experiments (Fig. 6). Since cis-vaccenate is the major unsaturated fatty acid product formed when assaying either of the two activities, one can not ascribe the first eluting activity to $\beta$-ketoacyl-ACP synthase II on the basis of its function in elongating palmitoleate to $c i s$-vaccenate.

Labelling of proteins was carried out with only $2 \mu \mathrm{mol} \cdot \mathrm{I}^{-1}\left[{ }^{3} \mathrm{H}\right]$-cerulenin, a concentration where inhibition of unsaturated fatty acid synthesis is just detectable. Two proteins which are probably both carrying out condensation reactions in fatty acid synthesis are found labelled to roughly the same extent. This implies that either the amount or the cerulenin sensitivity of the first eluting activity must be higher than that of $\beta$-ketoacyl-ACP synthase 1. Since the latter protein is abundant $(8,10,12)$, the other cerulenin binding protein is likely to be at least as sensitive to the inhibitor. This in turn implies that neither of these two activities can be involved in the saturated fatty acid synthesis observed in the presence of $20 \mu \mathrm{mol} \cdot \mathrm{l}^{-1}$ ceruleniñ.

The finding that a conditional unsaturated fatty acid auxotrophic E. coli strain is apparently missing $\beta$-ketoacyl-ACP synthase I supports the notion that the activities of the latter can be carried out by another enzyme. Is this the observed first eluting cerulenin binding protein? If so, then the unsaturated fatty acid synthetic activity of this enzyme may be temperature sensitive since the mutant exhibits a temperature dependant requirement for unsaturated fatty acids. This suggests a role of the latter enzyme in temperature regulation of $\mathrm{E}$. coli fatty acid composition.

\section{ACKNOWLEDGEMENTS}

PeTer F. Leadlay, University of Cambridge, England, is thanked for providing the $\left[{ }^{3} \mathrm{H}\right]$-cerulenin, John E. Cronan JR. and MEena NARASIMHAN, University of Illinois at UrbanaChampaign, USA, for the DM86 strain, and SAKARI KAUPPINEN, Carlsberg Laboratory, for the DM86 pfabB1 strain. GAMINI KANNANGARA is thanked for introducing me to fatty acid biosynthesis and protein purification, and for his never failing encouragements. I am indebted to PENNY VON WETTSTIIN-KNOWLES for stimulating discussions throughout the project and critical review of the manuscript. NINA RASMUSSEN and ANN-SOFI STEINHOLTZ are thanked for doing the drawings and pictures, respectively, HANNE THEM NiELSIN and LISE TRLLLT for typing the manuscript.

\section{REFERENCES}

1. BUTTKE, T.M. \& L.O. INGRAM: Inhibition of unsaturated fatty acid synthesis in Escherichia coli by the antibiotic cerulenin. Biochemistry 17, 52825286 (1978)

2. Cronan. J.E. JR.: Thermal regulation of the membrane lipid composition of Escherichia coli. Evidence for the direct control of fatty acid synthesis. J. Biol. Chem. 250, 7074-7077 (1975)

3. Cronan, J.E. JR., C.H. Birge \& P.R. Vagilos: Evidence for two genes specifically involved in unsaturated fatty acid biosynthesis in Escherichia coli. J. Bacteriol. 100, 601-604 (1969)

4. D.AGNOLO.G., I.S. ROSENFELD. J. AWAYA, S.ŌMURA \& P.R. VAGELOS: Inhibition of fatty acid synthesis by the antibiotic cerulenin, specific inactivation of $\beta$-ketoacyl acyl carrier protein synthetase. Biochim. Biophys. Acta 326, 155-166 (1973)

5. D.Agnolo, G. I.S. Rosenfeld \& P.R. Vagelos: Multiple forms of $\beta$-ketoacyl-acyl carrier protein synthetase in Escherichia coli. J. Biol. Chem. 250 , 5289-5294 (1975)

6. Epstein, W. \& C.F. Fox: Mapping of a locus for unsaturated fatty acid biosynthesis in Escherichia coli. J. Bacteriol. 103, 273-274 (1970)

7. Garwin. J.L.. A.L. KLAGeS \& J.E. Cronan JR.: $\beta$-ketoacyl-acyl carrier protein synthase II of $E s$ cherichia coli. Evidence for function in the ther- 
mal regulation of fatty acid synthesis. J. Biol. Chem. 255, 3263-3265 (1980)

8. Garwin, J.L., A.L. KlaGes \& J.E. Cronan JR.: Structural, enzymatic, and genetic studies of $\beta$-ketoacyl-acyl carrier protein synthases I and II of Escherichia coli. J. Biol. Chem. 255, 11949-11956 (1980)

9. Gelmann, E.P. \& J.E. CRONAN JR.: Mutant of $E s$ cherichia coli deficient in the synthesis of cisvaccenic acid. J. Bacteriol. 112, 381-387 (1972)

10. Herendeen, S.L., R.A. VanBogelen \& F.C. NeidHARDT: Levels of major proteins of Escherichia coli during growth at different temperatures. J. Bacteriol. 139, 185-194 (1979)

11. JACKOWSKI, S. \& C.O. Rock: Acetoacetyl-acyl carrier protein synthase, a potential regulator of fatty acid biosynthesis in bacteria. J. Biol. Chem. 262, 7927-7931 (1987)

12. KaupPinen, S., M. SigGaARd-ANDersen \& P. voN WETTSTEIN-KNOWLES: $\beta$-ketoacyl-ACP synthase I of Escherichia coli: Nucleotide sequence of the $f a b B$ gene and identification of the cerulenin binding residue. Carlsberg Res. Commun. 53, 357-370 (1988)

13. LAEMMLI, U.K: Cleavage of structural proteins during the assembly of the head of bacteriophage T4. Nature 227, 680-685 (1970)

14. Maniatis, T., E.F. Fritsch \& J. SambroOK: Molecular cloning. A laboratory manual. Cold Spring Harbor Laboratory, New York (1982)

15. MARR, A.G. \& J.L. InGRaham: Effect of temperature on the composition of fatty acids in Escherichia coli. J. Bacteriol. 84, 1260-1267 (1962)

16. Matsumae, A., Y. Kamio \& T. Hata: Studies on cerulenin. I. Studies on cerulenin producing strain. J. Antibiot. 16, 236-238 (1963)

17. Menioza, D. DE, A.K. UlRICH \& J.E. CRONAN JR.: Thermal regulation of membrane fluidity in $E s$ cherichia coli. Effects of overproduction of $\beta$-ketoacyl-acyl carrier protein synthase I. J. Biol. Chem. 258, 2098-2101 (1983)

18. Murray, N.E., W.J. Brammer \& K. MurRaY: Lambdoid phages that simplify the recovery of in vitro recombinants. Mol. Gen. Genet. 150, 53-61 (1977)

Accepted by S.O. ANDERSEN
19. Norris, A.T., S. Matsumura \& K. Bloch: Fatty acid synthetase and $\beta$-hydroxydecanoyl coenzyme A dehydrase from Escherichia coli. J. Biol. Chem. 239, 3653-3662 (1964)

20. Oxuyama, H., M. Saitoh \& R. Hiramatsu: Fatty acid synthetase system in the regulation of membrane lipid synthesis in Escherichia coli after shifts in temperature. J. Biol. Chem. 257, 4812-4817 (1982)

21. RAETZ, C.R.H.: Molecular genetics of membrane phospholipid synthesis. Ann. Rev. Genet. 20, 253295 (1986)

22. ROBERTS, G. \& P.F. LeAdLAY: [ $\left.{ }^{3} \mathrm{H}\right]$ Tetrahydrocerulenin, a specific reagent for radio-labelling fatty acid synthases and related enzymes. FEBS Lett. 159, 13-16 (1983)

23. Roberts, G. \& P.F. Leadlay: Use of $\left[{ }^{3} \mathrm{H}\right]$ tetrahydrocerulenin to assay condensing enzyme activity in Streptomyces erythreus. Biochem. Soc. Trans. 12, 642-643 (1984)

24. Rock, C.O. \& J.E. CRONAN JR.: Improved purification of acyl carrier protein. Anal. Biochem. 102, 362-364 (1980)

25. Rosenfeld, I.S., G. D.Agnolo \& P.R. VAGelos: Synthesis of unsaturated fatty acids and the lesion in fab B mutants. J. Biol. Chem. 248, 2452-2460 (1973)

26. SChairer, H.U. \& P. OVERATH: Lipids containing trans-unsaturated fatty acids change the temperature characteristic of thiomethylgalactoside accumulation in Escherichia coli. J. Mol. Biol. 44, 209-214 (1969)

27. SCheuerbrandt, G., H. Goldfine, E. Baronow. SKY \& K. BLOCH: A novel mechanism for the biosynthesis of unsaturated fatty acids. J. Biol. Chem. 236, PC 70 (1961)

28. SinENSKY, M:: Temperature control of phospholipid biosynthesis in Escherichia coli. J. Bacteriol. 106, 449-455 (1971)

29. VANCE, D., I.GOLDBERG, O. MitSUHASHI, K. BLOCK, S. ŌMURA \& S. NOMURA: Inhibition of fatty acid synthetases by the antibiotic cerulenin. Biochem. Biophys. Res. Commun. 48, 649-656 (1972) 